Please do not remove this page

RMIT

UNIVERSITY

\title{
From roots culture to sour fruit: the aesthetics of mobile branding cultures in Jamaica
}

Horst, Heather

https://researchrepository.rmit.edu.au/esploro/outputs/9921859840301341/filesAndLinks?institution=61RMIT_INST\&index=null

Horst, H. (2014). From roots culture to sour fruit: the aesthetics of mobile branding cultures in Jamaica.

Visual Studies, 29(2), 191-200. https://doi.org/10.1080/1472586X.2014.887272

Document Version: Accepted Manuscript

Published Version: https://doi.org/10.1080/1472586X.2014.887272

Repository homepage: https://researchrepository.rmit.edu.au

(C) 2014 International Visual Sociology Association

Downloaded On 2023/04/26 17:23:08 +1000

Please do not remove this page 
Thank you for downloading this document from the RMIT Research Repository.

The RMIT Research Repository is an open access database showcasing the research outputs of RMIT University researchers.

RMIT Research Repository: http://researchbank.rmit.edu.au/

\section{Citation:}

From roots culture to sour fruit: the aesthetics of mobile branding cultures in Jamaica', Visual Studies, vol. 29, no. 2, pp. 191-200.

See this record in the RMIT Research Repository at:

https://researchbank.rmit.edu.au/view/rmit:24600

Version: Accepted Manuscript

Copyright Statement: ‘ 2014 International Visual Sociology Association

Link to Published Version:

http://dx.doi.org/10.1080/1472586X.2014.887272 
Horst, Heather A. (2014) From roots culture to sour fruit: the aesthetics of mobile branding cultures in Jamaica. Visual Studies Volume 29, Issue 2, 2014, pp. 191-200. DOI:10.1080/1472586X.2014.887272

\author{
Special Issue: Visualising Ethnography: Ethnography's Role in Art and \\ Visual Cultures
}

\begin{abstract}
From aggressive marketing campaigns in print, television and billboards to corporate sponsorship of sporting events and corporate social responsibility programmes in the community, the logos, jingles, billboards and other forms of advertising are part and parcel of branded landscapes in which we live. Over the past decade, online, mobile and social media have also emerged as part of these branded landscapes. How have social media changed the ways in which companies and agencies develop and sustain relationships with potential consumers? Tracing the changes in the branding of telecommunications in Jamaica from public billboards and television advertisements (2001-2007) to forms of online advertising through social network sites such as Facebook (2008-2013), this article draws upon ethnographic research about interpretation of local and national culture by global telecommunications companies in the Caribbean. Building upon recent work in the study of consumption, new media as well as visual and sensory studies, I highlight the visual and aesthetic play and intimacy made possible through social media. I conclude by suggesting that social media expands the spaces for the consumption and circulation of mobile product and services and enables the aesthetic management of these products and services with consumers in novel ways.
\end{abstract}

\title{
Introduction
}

Arriving from the short 90-minute flight from Miami into Kingston's Norman Manley International airport, I unbuckled my seat belt, turned on my mobile phone and received a text message from Digicel Jamaica welcoming me to Jamaica and their 'Bigger, Better Network'. Just a few moments later, the signal had switched and I received a new welcome from Cable and Wireless Jamaica where my mobile signal decided to settle for the rest of my journey through the airport. I continued to be greeted by red Digicel Jamaica and green bMobile signs affixed to the bright, white air-conditioned hallways as I made my way to the arrivals and customs hall. More billboards surrounded me as we drove along the narrow strip of road leading into the city of Kingston welcoming me to Jamaica while boasting that they were the 'biggest', 'best' and 'only' choice for a mobile network throughout the island. While the example of mobile signals and branded airscapes may be more typical of business and leisure travellers, this branded experience is familiar to many Jamaicans going about their daily lives.

Horst, Heather A. (2014) From roots culture to sour fruit: the aesthetics of mobile branding cultures in Jamaica. Visual Studies Volume 29, Issue 2, 2014, pp. 191-200.

DOI:10.1080/1472586X.2014.887272 
Like other places in the world, the billboards and other monikers of the telecommunication companies' efforts to capture the imagination, hearts and pocketbooks of consumers in the global south have grown in intensity over the past decade (Doron and Jeffrey 2012; Goggin 2011; Horst and Miller 2006; Horst 2013; Mazzarella 2003). From aggressive marketing campaigns in print, television and billboards to corporate sponsorship of sporting events and corporate social responsibility programmes in the community, the logos, jingles, billboards and other forms of advertising place us in persistent relationships with a range of companies, services, products and platforms (Arvidsson 2005; Banet-Weiser 2007; Belk and Tumbat 2005; Ciochetto 2001; Foster 2011; Lury 2009, McCracken 1988, Slater 2011; Zukin 1993). While branding can be understood at its most fundamental level as 'mediators of social relationships' (Bevan and Wengrew 2010, 21), Sarah Banet-Wieser (2012) argues that we are now in a moment of 'brand cultures' wherein relationships with a variety of brands constitutes part of our everyday life, including our relationships with self and others. Branding cultures move beyond the shift to commodification to offer immaterial products such as emotion and affect as well as personalities and values.

Over the past decade, a series of new landscapes have emerged - online, mobile and social media - as locations for companies and advertising agencies to further develop brand cultures. These spaces come with new possibilities for uploading and sharing content, feedback mechanisms such as 'likes', 'followers', comments and other forms of participation on sites such as Facebook, Twitter, Instagram, YouTube and others (Banet-Wieser 2012; boyd 2010; Ellison and boyd 2013; Jenkins 2006). While originally taken up by individual users, companies and corporations interested in 'niche marketing' (see Chris Anderson's (2008) now classic book The Long Tail) began to recognise the value of some of the sociotechnical properties of social network sites and other social media. In particular, the persistence, replicability, scalability and searchability of social media enabled companies the possibility of one-to-one contact with particular consumers online, the ability to track consumers (and their networks) through the visibility of social media and test out marketing strategies and approaches directly to a community of consumers (boyd 2010; Burgess 2012).

This article examines advertising and branding in the mobile telecommunications industry in Jamaica to explore how relationships between consumers and citizens are changing through social media and social network sites. It draws upon previous and ongoing ethnographic research in the Caribbean (1999-2013) and South Pacific (2012 to present) focusing upon the relationship between mobile media, communication and social change in the two regions. 1 As part of this broader ethnographic research endeavour, it also includes an analysis of the Digicel Jamaica and LIME Caribbean (Jamaica) Facebook profiles and timelines over a 1-year period (August 2012-August 2013 ) to capture some of the changes from public billboards and television advertisements (2001-2007) to forms of online advertising through social network sites such as Facebook (2008-2013). Examining the visual play and

Horst, Heather A. (2014) From roots culture to sour fruit: the aesthetics of mobile branding cultures in Jamaica. Visual Studies Volume 29, Issue 2, 2014, pp. 191-200. 
intimacy made possible through social network sites and other social media, I integrate work in consumption and new media studies as well as visual and sensory studies to understand the ways in which social media not only expands the spaces for the consumption and circulation of mobile product and services but also enables the aesthetic management of these products and services with consumers in novel ways.

\section{PHASE I: COLOUR AND THE AESTHETICS OF ROOTS CULTURE}

As a commercially motivated practice, advertising cannot fall back to the claims of aesthetic 'autonomy' that are typically made on behalf of fine art...at the same time, because it deals in the concrete currency of images and because it is always involved in a project of aspirational transformation, it cannot be reduced to the purely instrumental calculus of the market either. William Mazzarella $(2003,103)$.

Within marketing and advertising cultures, colour has always been viewed as important in connecting to and shaping consumer relationships to brands and products due to ts capacity to link the sensory and the material (Aslam 2006; Geismar 2013; Grimes and Doole 1998; Madden, Hewlett, and Roth 2000; Mazzarella 2003). The meaning and significance of colour contributes to different senses of belonging and identify formation (Musharbash 2004; Saunders 2000; Wulff 2013; Young 2006). Drawing upon her research with the Anangu of South Australia, Diana Young (2011) suggests that colours have both semiotic and material properties that act in relation to each other, what she terms the 'sociality of colour'. The sociality of colour among the Anangu often emerges among artists who create continuity between their paint colours and clothing. They also integrate these colours in Australian National Football League jerseys, beanies and scarves. As Young describes the significance of these colour relationships, 'Australian Football League football strips have been appropriated by Anangu as a badge of identity and affiliation but also because these are readymade sets of colour. For Anangu such clothing expresses the potential for mutability and relatedness while at once being aesthetically desirable in its high contrasts of colors' $(2011,371)$. Young also notes that colours, which have tangible and intangible properties, are often multivalent, crossing a range of relationships, from individual and kinship identity to collective identities across local, national and transnational scales.

Within the context of Jamaica, three sets of colour relationships, or socialities, are prominent. The first is associated with Jamaica's national flag that features black and green panels separated by a gold ' $\mathrm{X}$ ' across it. Although the symbols have been interpreted slightly differently over time in relation to national identity and what Thomas (2004) describes as 'modern blackness', green most commonly symbolises Jamaica's lush and fertile land and vegetation. The flag's gold references Jamaica's shining sun while black signals the hardships of Jamaica's African majority population's past as well as the strength and (most recently) creativity to overcome adversity. The meaning and significance of

Horst, Heather A. (2014) From roots culture to sour fruit: the aesthetics of mobile branding cultures in Jamaica. Visual Studies Volume 29, Issue 2, 2014, pp. 191-200.

DOI:10.1080/1472586X.2014.887272 
Jamaica's national colours are explicitly discussed in the classroom and in the national curriculum. They are also communicated more broadly on television advertisements and special programming, especially in anticipation of emancipation (1 August 1834) and independence (6 August 1962) commemorations.

The second colour combination is red, gold and green, which is associated with the religion and culture of Rastafarianism. The Rastafarian movement began in Jamaica in the 1930s (Chevannes 1994) but has since spread throughout the world through reggae music and popular culture. The red-gold-green colour cluster originates from the Ethiopian flag during the Ethiopian Emperor Haile Selassie's reign (1930-1974); Rastafarians regard Haile Selassie as God incarnate. In the flag, red signals the blood of Jamaican martyrs, gold symbolises Africa's wealth and green reflects Jamaica's land, vegetation and Rastafarian's hope for the future. Garveyism, a precursor to Black Nationalism and Rastafarianism in Jamaica, introduced a third colour combination: red, black and green. The red, green and black flag symbolises blood and sacrifice (red), land, nature and freedom from oppression (green) and Jamaica's predominantly African population (black) (Shavishinsky 1998). Significantly, the colour combinations associated with Garveyism and Rastafarianism has become multivalent, particularly as they move throughout the globe through various pan-African movements and the global popularity of Bob Marley and reggae music. Jamaica's music, culture and the colour combinations, which encapsulate these, have been appropriated in the development of a global youth culture whose values both converge with and diverge from the intended significance of the Rastafarian movement and the black nationalism of Garveyism.

When the Irish telecommunications company Digicel Ltd. entered the Jamaican telecommunications market in 2001, the values associated with these particular colours were well established. Building upon the highly successful global marketing strategies of telecommunications companies such as Vodafone and Orange (Goggin 2006, 2010), Digicel hired Jamaican Harry Smith who led a highly successful marketing campaign at Red Stripe, a Jamaican beer company. Using vibrant colours associated with Rastafarianism and roots culture (Figure 2), Digicel presented themselves as the postcolonial alternative to the staid, conservative Cable and Wireless Jamaica who, having been in the Caribbean for almost 200 years, were associated with British colonial culture (Figure 1). Digicel also customised their logo to include green and red letters (Figure 2), rather than the monochromatic red logo used in other countries. 2 Alongside colours, Digicel effectively engaged in strategic corporate sponsorship of sports (e.g. track and field, football) and music events such as Digicel Rising Stars, a competitive music competition modelled on the international Pop Idol format (Horst and Miller 2006). In effect, Digicel successfully entered into cultural domains where Jamaicans pride themselves on being global leaders: music and sport. Digicel's customer base reportedly grew to over 100000 in 100 days due, in part, to its pricing structure, accessibility in rural areas and savvy advertising campaigns (Horst and Miller 2006). This format was used as a template for

Horst, Heather A. (2014) From roots culture to sour fruit: the aesthetics of mobile branding cultures in Jamaica. Visual Studies Volume 29, Issue 2, 2014, pp. 191-200. 
Digicel's expansion to other markets in the Caribbean (e.g. Haiti, see Baptiste, Horst, and Taylor 2010), Central America and the South Pacific.

FIGURE 1. Cable and Wireless Jamaica Logo on envelope, 2001. Photograph by the author, 2013.

FIGURE 2. Roots culture on Digicel Phonecard, 2004. Photograph by the author, 2013.

In contrast to Digicel, Cable and Wireless Jamaica used business blue and white in their advertising until 2005; prior to this time, Cable and Wireless' primary target marketing in advertising included business people as evidenced in the multiple advertisements with well-groomed Caribbean men clothed in white shirts and ties sitting behind large desks in their office. Other advertisements featured professional women juggling work and childcare responsibilities. In contrast to the youthful Reggae Boyz (who played football at the Olympics) and the highly successful Rising Stars music competition, Cable and Wireless were left with sponsorships like Reggae Sumfest that, while still popular with an older and wealthier generation, were less associated with hip, youth culture. In response to this association with business and bureaucracy, Cable and Wireless rebranded as bMobile. bMobile featured more competitive prices and, after 2005 , launched a fresh green and white logo and sponsored a series of humorous advertisements featuring aspects of Jamaican culture, such as men hiding the names of girlfriends from their wives or main girlfriends on their phones (Horst 2014). The bright green also facilitated aesthetic continuity with the green of the Jamaican flag, the green in roots colours and a visual contrast with Digicel's everpresent red signs that dotted the landscape throughout the country. Yet, as discussed in the following section, this rebranding did little to change the perception (and market share) of Cable and Wireless.

Digicel's harkening to roots culture through its integration of bold red conveyed energy and change. While in the early days of Digicel, the company was treated by some with uncritical celebration (particularly in rural Jamaica), most people were quite philosophical about the attachment to Digicel, noting that Cable and Wireless treated them badly when they were the sole mobile carrier. Indeed, people routinely referred to the company as 'Cable and Clueless', 'Cable and Worthless' and a range of other uncomplementary names. Moreover, most of the populace assumed (Irish-owned) Digicel was an American-owned, multinational corporation despite Digicel's belief that there would be an innate connection between the postcolonial politics of island nations. Rather, most Jamaicans were grateful to have access to telecommunications infrastructure of any kind, particularly one that enabled them to manage the cost of their calls through persecond billing. The dominance of bold red and white signs placed on jerseys,

Horst, Heather A. (2014) From roots culture to sour fruit: the aesthetics of mobile branding cultures in Jamaica. Visual Studies Volume 29, Issue 2, 2014, pp. 191-200. 
events and affixed to nearly every shop, stall and rural homes represented a visible symbol of Digicel's dominance and ability to deliver change.

\section{PHASE II: VYING FOR THE TASTE OF JAMAICA}

Driving into Half-Way-Tree (the business district in Jamaica's capital Kingston) in the summer of 2009, we came upon the offices of what was formerly known as Cable and Wireless/bMobile. Rather than the blue and white and green and white of Cable and Wireless' bMobile years (Figure 3), the side of the building was covered with black with a range of neon colours with big, bold white letters spelling out the acronym LIME (Figure 4). Cable and Wireless had rebranded itself again, this time featuring a suite of services including Landline, Internet, Mobile and Entertainment.3 A bold shift away from the blue and white of yore (which was gradually removed from any and all marketing and company literature), LIME represented an edgier, vibrant and fashionable palate to play with and a distinct aesthetic change from the neon green bMobile signs placed throughout the island. Yet, the rebranding was met with mixed response not just due to the fatigue many Jamaicans felt with Cable and Wireless; they also disliked the name itself. Indeed, when I noted that the urban and cosmopolitan sensibilities of the new LIME was a striking contrast to the previous branding campaign, my friend Nadine (a woman in her early 30s) replied, 'I don't know why they changed their name to that [sucks teeth in disgust]. Limes are sour and leave a bad taste in your mouth'. Nadine was not the only one left with a bad taste in her mouth. Others scrunched up their face like they were eating a raw lime and men jokingly referred to credit as 'lime juice'; while the juice of a lime is often squeezed on meat for seasoning or mixed in 'drinks' with syrup, sugar and water, it also has more negative references such as bodily discharge (Sobo 1993).

FIGURE 3. bMobile advertising campaign for Reggae Sumfest, 2006. Screenshot by the author, Frontline Mobile bMobile campaign. Frontline Marketing, Inc. Available online at: http://frontlinemarketing.net/bmobile/ [Accessed July 2013].

FIGURE 4. LIME Jamaica head office. Photograph by GK Smith Landscapes. Available online at: http://www.flickr.com/photograph s/gksphotograph/8501546075/ [Accessed August 2013].

The aesthetic failure of LIME can be explained, in part, by the tension exemplified in what Wilken and Sinclair (2009a, 2009b) describe as an increasing trend towards 'strategic regionalism' by multinational companies who are grappling with how to manage the global and the local. Moving beyond geographic reductionism implied in the concept of the region, strategic regionalism is an attempt by companies to look at cross-national similarities and differences such as linguistic and cultural similarities as well as regulatory environments. The combination of global strategic marketing and advertising strategies with local adaptations has been employed in marketing campaigns ranging from Coca-Cola,

Horst, Heather A. (2014) From roots culture to sour fruit: the aesthetics of mobile branding cultures in Jamaica. Visual Studies Volume 29, Issue 2, 2014, pp. 191-200.

DOI:10.1080/1472586X.2014.887272 
mobile phones, children's toys and other commodities and services (Ciochetto 2011; Cook 2011; Dávila 2012; Foster 2002, 2007; Mazzarella 2003; Miller 1997). While motivated to change Cable and Wireless/bMobile/LIME's market share in Jamaica, LIME's rebranding was targeted at the broader Caribbean region. Indeed, LIME was renamed as LIME Caribbean, the name change viewed as indicative of a fight for the Anglophone and Francophone Caribbean region where Digicel continued to dominate the market (Dunn 2012; Business Suite Magazines 2007). As Mariano Doble (Executive Vice President Commercial, LIME Caribbean) explained the rebranding aims, 'In the Caribbean "lyme" actually means chill out and that is what our customers want and we want to deliver it so that they love us - which they don't now' (quoted in Hall 2008). Doble also describes how the focus is moving from the products and services to building stronger relationships with their customers.

Although the naming of the company as LIME did not sit well with many Jamaicans, LIME's rebranding strategy also corresponded with the increased availability and affordability of smartphones and Blackberries as well as higher Internet penetration rates. This transformation extended the branded landscapes from billboards, sports arenas, shop fronts and trash heaps filled with phone cards in Jamaica's towns and streets into world of social media. Indeed, each company established profiles on sites such as Facebook, YouTube, Instagram and Twitter. Like Coca-Cola in Papua New Guinea (Foster 2002), LIME developed connections with national symbols, national colours and national fruit, as exemplified in the billboard, shown in Figure 5, celebrating 50 years of Jamaican independence in August 2012. Rather than use the green associated with bMobile, LIME's online presence shifted to gold (their Facebook logo often oscillates between green and gold), a move that creates aesthetic continuity between the Jamaican flag and the Rastafarian flag. LIME also celebrated Digicel's brand Ambassador Usain Bolt's and others' victories and accomplishments in track and field. Digicel's social media profile, by contrast, focused the aspirational consumer aesthetic it had been carefully honing for over 6 years. 4 The company's recent campaign, 'Be Extraordinary', highlighted imagined futures and provided its Facebook followers with an intimate peek at Jamaica's movers and shakers, such as through informal, behind-the-scene photographs with Digicel star contestants and judges.

FIGURE 5. LIME advertisement with Ackee, Jamaica's National Fruit, 2012. Facebook screenshot by the author, August 2013.

\section{TASTING SWEET AND SOUR FRUIT ON FACEBOOK}

Something sweet is ready to eat or ripe for enjoyment ... a dream of fruit at its fullest, sweetest stage of development means the time is right ... [one must] seize the moment. Elisa Sobo $(1993,32)$

Horst, Heather A. (2014) From roots culture to sour fruit: the aesthetics of mobile branding cultures in Jamaica. Visual Studies Volume 29, Issue 2, 2014, pp. 191-200.

DOI:10.1080/1472586X.2014.887272 
The aesthetics of appropriation discussed in the previous section highlights the ways in which national cultures, symbols and, as evidenced in the LIME campaign, meanings are employed in the minute interactions between companies and consumers on Facebook. Yet, the participatory dimensions of Facebook that structure participation by calling for 'friends' to comment on posts, update a status and express (most recently) what's on your mind require 'friends' like Facebook and LIME to move beyond the messaging historically used in advertising. Digicel, which posts more frequently than LIME, features insider pictures of contestants on Digicel Rising Stars, Usain Bolt, promotions and a range of new services. They also post the kind of banal pictures associated with the networked public culture (e.g. kittens, 'cute' pictures of children) circulated on 'ordinary' Facebook users' timelines (Horst 2009). By contrast, LIME's semiotic work on Facebook explicitly focused upon managing the brand identity of LIME in two ways. The first involved the notion of 'playful' and fun associated with the concept of 'liming' in the Caribbean (Miller 1994), a goal most directly met through the posting of Jamaicans attending parties, festivals and fetes often co-sponsored by LIME. The second and more interesting strategy involved a series of postings directed at counteracting the association of LIME with sour limes.

The focus upon thwarting LIME's association with sourness invoked the connection between the visual culture and the sensory nature of taste, especially of fruit through two core strategies. First, LIME regularly posted pictures of yellow and green fruit of Jamaica (e.g. bananas, plantains) that visually aligned with its yellow or green LIME logo on Facebook. For example, in July 2013, LIME reposted a photograph of a LIME billboard originally displayed around Jamaica's Fiftieth Anniversary of independence in the summer of 2012. Among other national symbols (the flag and a hummingbird), the photograph features the LIME logo in the centre and includes one of Jamaica's national fruit, ackee. The pear-shaped ackee shown in the photograph is ripe and open, revealing three large, shiny black seeds that are surrounded by yellow flesh; the ripe fruit is notably attached directly to the LIME logo. The billboard's words, 'Out of Many, Only One Network has our Shared History', placed on the billboard's yellow background seeks to intertwine LIME Jamaica with the cultural history and development of Jamaica. In posting this to Facebook, LIME Jamaica's community manager harkens to this shared history by reinvoking 'Out of Many, One People' (Jamaica's motto), and the company's ability to connect Jamaicans spread throughout the globe. The fact that this picture can be reposted a year later remains one of the salient features of social media for companies like LIME and Digicel.

The negative associations with LIME and sour fruit were not lost on Digicel who, over the years since LIME launched, have countered with their own advertisements on billboards which they also post and repost on their social media pages. Responding to LIME's attempts to visually connect their new gold aesthetic with fruit that has positive or sweet properties, Digicel developed a

Horst, Heather A. (2014) From roots culture to sour fruit: the aesthetics of mobile branding cultures in Jamaica. Visual Studies Volume 29, Issue 2, 2014, pp. 191-200. 
billboard, which not so subtly reminded consumers of the sour taste of limes. The advertisement features a young, light-skinned slim woman holding her (presumably) Digicel phone and a pineapple speaking to a female vendor (or higgler) dressed in a modern bright pink T-shirt and a tartan plaid headscarf, a traditional Jamaican headscarf worn by the peasantry during emancipation.5 Although whether the vendor is asking the lady if she has a LIME phone or the lady is asking the vendor if she has any limes is ambiguous, the fact the lady 'DON'T HAVE ANY LIME' (in bold letters, like the name of the company) hints at the inaccessibility of LIME and the sour taste that LIME leaves in one's mouth (Figure 6).

FIGURE 6. Digicel advertisement 'U DONT HAVE ANY LIME', 2013. Facebook screenshot by the author, July 2013.

LIME also developed other advertisements and strategies to counteract Digicel and the wider public's continued association of LIME with sour fruit. Figure 7 shows the picture of guinep fruit, which was posted on LIME Jamaica's Facebook page in late August 2013 in the middle of guinep season. With a delicate, sweet taste and texture similar to lychee, guineps (called Spanish Limes in other countries) are often sold in bags by the roadside. Highlighting the succulence of the fruit in the photograph, the community manager explicitly uses the word sweet to describe the summer fruit, suggesting a pleasurable association with LIME; it is notably one of the most 'liked' images posted by LIME in this period. Digicel continued to push the association between sour fruits and LIME in a recent campaign (June 2013) by offering a range or 'variety' of pricing structures. Focusing upon choice and the pleasures of 'freeness', the advertisement features a range of sweet and colourful lollipops with 'sprinkles', which are suggestive of the 'extras' that come with the plans. Moreover, the advertisement features two yellow lollipops underneath the quote 'BECAUSE LEMON FLAVOUR ISN'T FOR ALL' (Figure 8), a statement that highlights the difference between sweetness and sour that continues across the series of advertisements posted and reposted on Facebook. This connotation is even more explicit in Figure 9, which explicitly states that Digicel has 'Jamaica's Sweetest Plan'.

FIGURE 7. LIME post highlighting the sweetness of guinep fruit, 2013. Facebook screenshot by the author, July 2013.

FIGURE 8. Digicel advertisement 'BECAUSE LEMON FLAVOUR ISN'T FOR ALL'. Screenshot captured on Facebook by the author, August 2013.

FIGURE 9. Digicel advertisement 'Jamaica's Sweetest Plan'. Screenshot captured on Facebook by the author, August 2013.

Horst, Heather A. (2014) From roots culture to sour fruit: the aesthetics of mobile branding cultures in Jamaica. Visual Studies Volume 29, Issue 2, 2014, pp. 191-200.

DOI:10.1080/1472586X.2014.887272 
The appeal to taste that LIME and Digicel attempt to evoke represents a key example of the kinds of intimacy and authenticity characteristic of today's brand cultures. At the level of semiotics, the visual, verbal and sensory play with sweetness featured in the advertisements reflects a broader sensibility around the significance of sweetness and word play. Sweetness in Jamaican vernacular is often used to describe looking healthy and plump, having a pleasant smell and the feeling of happiness and pleasure. The gold or yellow colour of fruit - from bananas and plantain to ackee - also signals fruit is ripe and ready to be eaten. More salaciously, sweetness is also a term used to refer to sexiness and sexual readiness. Green, by contrast, is associated with being unripe; its incorporation in the mouth and body is considered premature and therefore problematic (Sobo 1993). 6 The imagery around fruit and sweetness speaks to the broader ontology of food, fruit and the body in Jamaica, the implication of the consumption of sweet (not sour) things signalling the incorporation in the body and, by extension, the body politic of Jamaicans. Yet, beyond the semiotic work that the advertising and marketing arms of LIME and Digicel undertake, there are also materialist connotations of the play between sweetness and sour worth noting.7 As Sidney Mintz (1985) has so cogently highlighted in Sweetness and Power, Jamaica was a central node of production in the global sugar trade and associated industries (e.g. rum). As the first successful market for Digicel, Jamaica is one of the models for Digicel's global telecommunications strategy and one whose heroes and culture travel as part of the Digicel brand from Jamaica to Papua New Guinea, Fiji and Tonga.

\section{CONCLUSION: INTIMACY AND THE AESTHETICS OF BRANDING THROUGH SOCIAL MEDIA}

This article sets out to address the question of how social media are becoming integrated into the creation of brand cultures through an analysis of the transformations in branding aesthetics by two telecommunications companies, Digicel and LIME (formerly Cable \& Wireless Jamaica). As Sarah Banet-Wieser recently observed, in the twenty-first century, 'branding and advertising strategies are increasingly complex, especially in a digital media environment where viral advertisements, guerrilla marketing, online consumer campaigns and competitions, and user feedback mechanisms are ways for corporations to script advertising messages that feel distinctly noncommercial, and therefore authentic' $(2012,11)$. Particularly prominent in this analysis is the ability of each telecommunications company to engage in regular and routine communications between Facebook 'friends', Twitter 'followers' and other social media sites to, in effect, micromanage the images of their companies, what Foster (2007) refers to as the process of qualification and requalification.

With social media, the process of qualification is shaped by the 'participatory' quality of social media and social network sites (boyd 2010; Ellison and boyd 2013; Jenkins 2006). While both companies clearly appear as 'companies' and must be 'liked' to be seen in one's Facebook timeline, once the 'like' button is

Horst, Heather A. (2014) From roots culture to sour fruit: the aesthetics of mobile branding cultures in Jamaica. Visual Studies Volume 29, Issue 2, 2014, pp. 191-200.

DOI:10.1080/1472586X.2014.887272 
clicked, their notifications appear in one's timeline alongside one's Facebook 'friends'. Although the initial motivation to 'like' Digicel or LIME on Facebook may be tied to accessing a special or promotion, the flattening structures of participation on a site like Facebook places one in a peer-to-peer relationship with the company. This relationship can be managed, blocked or 'unliked', but it must be managed in the same way one manages other Facebook friends and groups. In effect, the social media profile and the structures of participation on Facebook effectively treat companies like persons with whom you have one-toone relationships with rather than one-to-many relationships characteristic of the broadcast advertising era through radio, television and newspapers. As company-person-friend, companies possess the ability to create a sense of closeness and intimacy by posting through networked public culture, such as pictures of food, sharing inspirational quotes or 'cute' photographs. By reminding people of the sweet taste of mangoes or collective event and the sense of 'being there' (what Johannes Fabian (2002) describes as co-evalness), community managers at companies effectively use social media sites to develop a persona of the company as a company-person-friend who possesses values, personalities, emotions and, as highlighted most explicitly in the discussion of sweetness and sour, similar tastes (Banet-Wieser 2012; Howes 2005). Indeed, it is not unusual to see a query about service or difficulties with a phone requesting help from their 'friend' Digicel or LIME posted in comments. As company-personfriend on a social network site such as Facebook, companies effectively utilise the one-to-one relationships with consumers to track at the individual and aggregate level through likes, comments, metrics and other responses to the company. This facilitates new ways of imagining the company and products, often without the formalised market research used in previous decades. In the age of brand cultures, social media provides a venue through which new forms of company-consumer relationships can be developed, sustained and, at times, made intimate.

\section{Notes}

[1] The material (e.g. fieldnotes, bulletins, newspaper clippings, advertisements, billboards, television advertisements and so on) and analysis for this article draws upon my long-term ethnographic engagement in Jamaica, beginning in 1994 as an undergraduate student teaching at a primary school in rural Jamaica. I later carried out ethnographic fieldwork (in country) on returning residents in Mandeville, Jamaica, between 1999 and 2001, low-income Jamaicans' use of Information and Communication Technologies in rural and urban Jamaica in 2004 and have returned in 2006, 2007, 2009 and 2011 for shorter visits. My work on telecommunications culture and Digicel outside of Jamaica began developing through an IMFTI-funded project on migrants, mobiles and mobility on the border of Haiti and the Dominican Republic between 2010 and 2012, the PACMAS Baseline Study in the Pacific region beginning in 2012 and the Gender of Money Project in 2013. In 2014, I will begin a comparative study of mobile telecommunications in Fiji and Papua New Guinea. 
[2] Digicel also customised the logo for Digicel Fiji (blue and red), a market where Digicel has struggled to gain customers.

[3] LIME's rebranding was not motivated only by the desire to compete with Digicel in Jamaica (although its financial loss was clearly a motivating factor); a new service Flow (Columbus Communications) began offering Landline, Internet and Cable Television (see Dunn 2012 for broader discussions of telecommunications policies in the region).

[4] By 2008, Digicel still dominated the market, but the sheen was also fading. It was also a period of rapid expansion into other markets in the Caribbean including Haiti (now Digicel's most profitable market in the region), Central America and the South Pacific (Horst 2013).

[5] While it is outside the scope of this article, the use of the word 'lady' and the admiration of the modern young woman by the half modern, half traditionally dressed higgler also hints at the aesthetic aspirations evinced in and through mobile phones.

[6] It is interesting that LIME has not (yet) responded to Digicel's play on sweetness by suggesting that they are overripe or indulgent. As Sobo (1993) discusses at length, there is a great concern with avoiding overripe or foul fruit as it softens, darkens and rots. Similarly, overindulgence in food, sweets and drinks is also viewed negatively as it suggests imbalance (see also Chevannes 1989).

[7] As sociologist Peter Espeut (2012) captures in his editorial on public statements by LIME's CEO Chris Dehring, 'The 2008 change of name to LIME cannot erase the memory of the sins of C\&W'. Indeed, LIME Jamaica has not reported a profit since 2007.

\section{REFERENCES}

1. Anderson, C. 2008. The Long Tail: Why the Future of Business Is Selling Less of More. New York: Hyperion.

2. Arvidsson, A. 2005. "Brands: A Critical Perspective." Journal of Consumer Culture 5: 235-258.

3. Aslam, M. M. 2006. "Are You Selling the Right Colors? A Cross-Cultural Review of Colors as a Marketing Cue." Journal of Marketing Communications 12 (1): 15-30.

4. Banet-Weiser, S. 2007. Kids Rule! Nickelodeon and Consumer Citizenship. Durham, NC: Duke University Press.

5. Banet-Wieser, S. 2012. AuthenticTM: The Politics of Ambivalence in a Brand Culture. New York: NYU Press.

6. Baptiste, E., Horst, H., and Taylor, E. 2010. Haitian Monetary Ecologies. Report Submitted to the Institute for Money, Technology and Financial Inclusion November 2010. Accessed January 10, 2011.

http://issuu.com/bill_maurer/docs/baptiste_horst_taylor_112310?viewMode=m agazine

7. Belk, R. W., and G. Tumbat. 2005. "The Cult of Macintosh." Consumption Markets \& Culture 8 (3): 205-217.

Horst, Heather A. (2014) From roots culture to sour fruit: the aesthetics of mobile branding cultures in Jamaica. Visual Studies Volume 29, Issue 2, 2014, pp. 191-200. 
8. Bevan, A., and D. Wengrew. 2010. Cultures of Commodity Branding. Walnut Creek, CA: Left Coast Press.

9. boyd, d. M. 2010. "Social Network Sites as Networked Publics: Affordances, Dynamics, and Implications." In Networked Self: Identity, Community, and Culture on Social Network Sites, edited by Z. Papacharissi, 39-58. London: Routledge.

10. Burgess, J. 2012. "The iPhone Moment, the Apple Brand, and the Creative Consumer: From 'Hackability and Usability' to Cultural Generativity." In Studying Mobile Media Cultural Technologies, Mobile Communication, and the iPhone, edited by L. Hjorth, J. Burgess, and I. Richardson, 28-42. New York: Routledge.

11. Business Suite Magazines. 2007 "Can Phil Do It? Make a Difference at Cable and Wireless That Is." Business Suite Magazine, November 5. http://www.businessuiteonline.com/2007/11/05/can-phil-do-it-make-adifference-at-cable-and-wireless-that-is/

12. Chevannes, B. 1989. "Drop Pan and Folk Consciousness." Jamaica Journal 22 (2): 45-50.

13. Chevannes, B. 1994. Rastafari: Roots and Ideology. Syracuse, NY: Syracuse University Press.

14. Ciochetto, L. 2001. "Outdoor Advertising and Social Change in Contemporary Russia." Media International Australia, Incorporating Culture \& Policy 101: 101-110.

15. Ciochetto, L. 2011. "Advertising and Value Formation: The Power of Multinational Companies." Current Sociology 59: 173-185. , [Web of Science $®$ ]

16. Cook, D. T. 2011. “Commercial Epistemologies of Childhood: 'Fun' and the Leveraging of Children's Subjectivities and Desires." In Inside Marketing: Practices, Ideologies Devices, edited by D. Zwick and J. Cayla, 257-268. Oxford: Oxford University Press.

17. Dávila, A. 2012. Latinos, Inc.: The Marketing and Making of a People. 2nd ed. Berkeley: University of California Press.

18. Doron, A., and R. Jeffrey. 2012. The Great Indian Phone Book: How the Cheap Cell Phone Changes Business, Politics and Everyday Life. Cambridge, MA: Harvard University Press.

19. Dunn, H. S., ed. 2012. Ringtones of Opportunity: Policy, Technology and Access in Caribbean Communications. Kingston: Ian Randle Publishers.

20. Ellison, N. B., and d. boyd. 2013. "Sociality through Social Network Sites." In The Oxford Handbook of Internet Studies, edited by W. H. Dutton, 151-172. Oxford: Oxford University Press.

21. Espeut, P. 2012. "The Wages of Sin." The Jamaica Gleaner, January 27. http://jamaica-gleaner.com/gleaner/20120127/cleisure/cleisure2.html

22. Fabian, J. 2002. Time and the Other: How Anthropology Makes its Object. New York: Columbia University Press.

23. Foster, R. J. 2002. Materializing the Nation: Commodities, Consumption and the Media in Papua New Guinea. Bloomington: Indiana University Press.

24. Foster, R. J. 2007. "The Work of the New Economy: Consumers, Brands, and Value Creation." Cultural Anthropology 22 (4): 707-731. , [Web of Science ®] 
25. Foster, R. J. 2011. "The Uses of Use Value: Marketing, Value Creation, and the Exigencies of Consumption Work." In Inside Marketing: Practices, Ideologies Devices, edited by D. Zwick and J. Cayla, 42-57. Oxford: Oxford University Press.

26. Geismar, H. 2013. Treasured Possessions: Indigenous Interventions into Cultural and Intellectual Property. Durham, NC: Duke University Press.

27. Goggin, G. 2006. Cell Phone Culture: Mobile Technology in Everyday Life. London: Routledge.

28. Goggin, G. 2010. Global Mobile Media. London: Routledge.

29. Goggin, G. 2011. Global Mobile Media. London: Routledge.

30. Grimes, A., and I. Doole. 1998. "Exploring the Relationship between Color and International Branding." Journal of Marketing Management 14: 799-817.

31. Hall, A. 2008. "New Name, New Frame - C\&W Now LIME, Ready to Fight for Market Share.” Jamaica Gleaner, Sunday, November 2. http://jamaicagleaner.com/gleaner/20081102/business/business1.html

32. Horst, H. A. 2009. "Aesthetics of the Self: Digital Mediations." In Anthropology and Individuals: A Material Culture Approach, edited by D. Miller, 99-114. New York: Berg.

33. Horst, H. A. 2013. "The Infrastructures of Mobile Media: Towards a Future Research Agenda." Mobile Media \& Communication 1 (1): 147-152.

34. Horst, H. A. 2014. "Calling My Name: Sound, Orality and the Cell Phone Contact List." In The Oxford Handbook of Mobile Media and Sound, Vol. 1, edited by S. Gopinath and J. Stanyek. Oxford: Oxford University Press.

35. Horst, H. A., and D. Miller. 2006. The Cell Phone: An Anthropology of Communication. Oxford: Berg.

36. Horst, H. A., and D. Miller, eds. 2012. Digital Anthropology. Oxford: Berg.

37. Howes, D., ed. 2005. "Hyperethesia, or the Sensual Logic of Late Capitalism.” In Empire of the Senses: The Sensory Culture Reader, 281-303. Oxford: Berg.

38. Ito, M., S. Baumer, M. Bittanti, d. boyd, R. Cody, R. Herr-Stephenson, H. A. Horst, P. G. Lange, D. Mahendran, K. Z. Martinez, C. J. Pascoe, D. Perkel, L. Robinson, C. Sims, and L. Tripp. 2010. Hanging Out, Messing Around, and Geeking Out: Kids Living and Learning with New Media. Cambridge, MA: MIT Press.

39. Jenkins, H. 2006. Fans, Bloggers, and Gamers: Exploring Participatory Culture. New York: New York University Press.

40. Lury, C. 2009. "Brand as Assemblage: Assembling Culture." Journal of Cultural Economy 2 (1-2): 67-82.

41. Madden, T. J., K. Hewlett, and M. S. Roth. 2000. "Managing Images in Different Cultures: A Cross-National Study of Color Meanings and Preferences." Journal of International Marketing 8 (4): 90-107. , [Web of Science ®]

42. Mazzarella, W. 2003. Shoveling Smoke: Advertising and Globalization in Contemporary India. Durham, NC: Duke University Press.

43. McCracken, G. 1988. Culture and Consumption: New Approaches to the Symbolic Character of Consumer Goods and Activities. Bloomington: Indiana University Press.

44. Miller, D. 1994. Modernity an Ethnographic Approach: Dualism and Mass Consumption in Trinidad. Oxford: Berg. 
45. Miller, D. 1997. Capitalism: An Ethnographic Approach. Oxford: Berg. 46. Mintz, S. 1985. Sweetness and Power: The Place of Sugar in Modern History. New York: Viking.

47. Musharbash, Y. 2004. "Red Bucket for the Red Cordial, Green Bucket for the Green Cordial: On the Logic and Logistics of Warlpiri Birthday Parties." The Australian Journal of Anthropology 15: 12-22.

48. Saunders, B. A. C. 2000. "Revisiting Basic Color Terms." Journal of the Royal Anthropological Institute (N.S.) 6: 81-98. , [Web of Science $\circledR$ ], [CSA] 49. Shavinshiky, N. 1998. "The African Origins of Jamaica's Rastafarian Movement." In Chanting Down Babylon, edited by N. S. Murrell, W. D. Spencer, and A. A. McFariane. Philadelphia, PA: Temple University Press.

50. Slater, D. 2011. "Marketing as Monstrosity: The Impossible Place between Culture and Economy." In Inside Marketing: Practices, Ideologies Devices, edited by D. Zwick and J. Cayla, 23-41. Oxford: Oxford University Press.

51. Sobo, E. J. 1993. One Blood: The Jamaican Body. Albany: State University of New York Press.

52. Thomas, D. 2004. Modern Blackness: Nationalism, Globalization, and the Politics of Culture in Jamaica (Latin America Otherwise). Durham, NC: Duke University Press.

53. Wilken, R., and J. Sinclair. 2009a. "Strategic Regionalization in Marketing Campaigns: Beyond the Standardization/Glocalization Debate." Continuum: Journal of Media and Cultural Studies 23 (2): 147-157.

54. Wilken, R., and J. Sinclair. 2009b. "Contests of Power and Place in Mobile Media Advertising." Australian Journal of Communication 36 (1): 85-109.

55. Wulff, H. 2013. "Ways of Seeing Ireland's Green: From Ban to the Branding of a Nation." The Senses and Society 8 (2): 233-239.

56. Young, D. 2006. "The Colors of Things." In The Handbook of Material Culture, edited by P. Spyer, C. Tilley, S. Kuechler, and W. Keane’s, 173-185. London: Sage Publications.

57. Young, D. 2011. "Mutable Things: Colors as Material Practice in the North West of South Australia." Journal of the Royal Anthropological Institute 17 (2): 356-376.

58. Zukin, S. 1993. Landscapes of Power: From Detroit to Disney World. Berkeley, CA: University of California Press. 